\title{
Aktif erkek bireylerde tek seans uygulanan izokinetik egzersizin DNA hasarı üzerine etkilerinin incelenmesi
}

\author{
Investigation of the effects of an acute bout of isokinetic exercise on DNA damage in \\ active male subjects
}
Emine Kılıç-Toprak, Fatma Ünver, Özgen Kılıç-Erkek, Halil Korkmaz, Burak Oymak, Yasin Özdemir, Alten Oskay, Vural Küçükatay, Melek Bor-Küçükatay

Gönderilme tarihi:25.09.2018

Kabul tarihi:23.11.2018

Özet

Amaç: İzokinetik egzersiz, kas kuvvet dengesizliğini azaltmak ve performansı arttırmak için kullanılır. Önceki çalışmalarda, farklı egzersiz türlerinin DNA üzerinde yaptığı değişiklikler araştırılmış olmakla birlikte, aktif bireylerde izokinetik test cihazıyla uygulanan eksantrik tipte egzersizin Comet analiziyle değerlendirilen DNA hasarı üzerine etkisi bilinmemektedir. Bu çalışmada, tek seans uygulanan izokinetik egzersiz protokolünü takiben olası DNA hasarının zamana bağlı değişikliklerinin incelenmesi amaçlanmıştır.

Gereç ve Yöntem: Çalışmamıza 11 sağlıklı aktif erkek birey dahil edilmiştir (ort yaş 19.45 \pm 0.31 , vücut kütle indeksi $22.05 \pm 0.51 \mathrm{~kg} / \mathrm{m} 2$ ). Bireylerin dominant diz fleksiyon/ekstansiyon kuvvetleri izokinetik dinamometre (Humac Norm Testing Rehabilitation system, CSMI Medikal Solutions, USA) kullanılarak ölçülmüştür. Quadriceps ve hamstring izokinetik kas kuvvetleri $30 \mathrm{o} / \mathrm{s}$ ve $120 \mathrm{o} / \mathrm{s}$ açısal hızlarda eksantrik modda test edilmiştir. Bireylerden egzersiz öncesi, hemen sonrası ve 2 gün sonra alınan venöz kan örneklerinde, DNA hasarı belirlenmesinde Comet analizi kullanılmıştır. İstatistiksel analiz için Friedman testi kullanılmış, $p \leq 0.05$ değerleri istatistiksel olarak anlamlı kabul edilmiştir.

Bulgular: İzokinetik egzersizin DNA hasarına etkileri incelendiğinde; kuyruk uzunluğu (18.76 \pm 3.08 'e karşın 16.21 $\pm 1.14 ; p=0.027$ ) egzersizden hemen sonra alınan kan örneklerinde azalırken, 2 gün sonra post-egzersiz

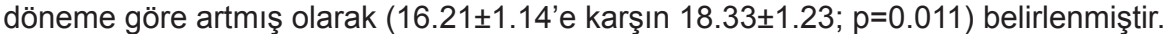

Sonuç: Kuyruk uzunluğu azalması DNA hasarı azalmasıyla doğru orantılıdır. Egzersizden hemen sonra azalan kuyruk uzunluğu, uygulanan izokinetik egzersizin genotoksisite üzerine olumlu etkide bulunabileceğini düşündürmektedir. Olumlu etki 2 gün içinde geri dönmektedir.

Anahtar Kelimeler: İzokinetik egzersiz, DNA hasarı, eksantrik egzersiz.

Kılıç Toprak E, Ünver F, Kılıç Erkek Ö, et al. Aktif erkek bireylerde tek seans uygulanan izokinetik egzersizin DNA hasarı üzerine etkilerinin incelenmesi. Pam Tıp Derg 2019;12:33-40.

\begin{abstract}
Purpose: Isokinetic exercise is used to reduce strength imbalance and to enhance performance. Although previous studies presented alterations on DNA induced by different exercise types; effects of eccentric type of exercise applied with an isokinetic test device on DNA damage assessed by Comet analysis is not known. The effect of the Present study was designed to explore the time course of possible DNA damage following an acute bout of isokinetic exercise.

Materials and Methods: 11 healthy, male, active subjects (mean age 19.45 \pm 0.31 , Body mass index 22.05 \pm 0.51 ) were enrolled. They performed eccentric contractions of knee flexors and extensors with dominant leg on a dynamometer (Humac Norm Testing Rehabilitation system, CSMI Medical Solutions, USA). Isokinetic hamstring,
\end{abstract}

Emine Kılıç-Toprak, Dr.Öğr.Üyesi, Pamukkale Üniversitesi, Tıp Fakültesi, Fizyoloji Ana Bilim Dalı, DENiZLi, e-posta:ektoprak@yahoo.com (orcid.org/0000-0002-8795-0185) (Sorumlu yazar)

Fatma Ünver, Doç. Dr. Pamukkale Üniversitesi, Fizik Tedavi ve Rehabilitasyon Yüksekokulu, DENiZLi, e-posta: funver@pau.edu.tr (orcid. org/0000-0002-3100-0818)

Özgen Kılıç-Erkek, Araş Gör. Pamukkale Üniversitesi, Tıp Fakültesi, Fizyoloji Ana Bilim Dalı, DENiZLí, e-posta:oerkek@pau.edu.tr (orcid. org/0000-0001-8037-0991)

Halil Korkmaz, Öğretim Gör. Gedik Üniversitesi, Spor Bilimleri Fakültesi, ISTANBUL, e-posta:hkorkmaz@gu.edu.tr (orcid.org/0000-00015587-5195)

Burak Oymak, Arş. Gör. Pamukkale Üniversitesi, Tıp Fakültesi, Fizyoloji Ana Bilim Dalı, DENiZLi̇, e-posta:boymak@pau.edu.tr (orcid. org/0000-0002-2887-0783)

Yasin Özdemir, Arş.Gör. Pamukkale Üniversitesi, Tıp Fakültesi, Fizyoloji Ana Bilim Dalı, DENiZLi, e-posta:yozdemir@pau.edu.tr (orcid. org/0000-0002-7562-0744)

Alten Oskay Dr.Öğr.Üyesi, Süleyman Demirel Üniversitesi Tıp Fakültesi, Acil Tıp Ana Bilim Dalı, ISPARTA, e-posta: oskayten@pau.edu.tr (orcid.org/0000-0003-4373-6280)

Vural Küçükatay, Prof.Dr. Pamukkale Üniversitesi, Tıp Fakültesi, Fizyoloji Ana Bilim Dalı, DENiZLi, e-posta: vkucukatay@pau.edu.tr (orcid. org/0000-0002-6850-6281)

Melek Bor-Küçükatay, Prof.Dr. Pamukkale Üniversitesi, Tıp Fakültesi, Fizyoloji Ana Bilim Dalı, DENiZLi, e-posta: mbor@pau.edu.tr (orcid. org/0000-0002-9336-0205) 
quadriceps strength was recorded at eccentric $\left(30,120^{\circ} \mathrm{s}-1\right)$ angular velocities. Blood was obtained before, after and 2 days following the exercise. DNA damage was measured by Comet analysis. Friedman test was used for statistical analysis, $p \leq 0.05$ was considered statistically significant.

Results: In terms of DNA damage parameters following isokinetic exercise tail length $(18.76 \pm 3.08$ vs. $16.21 \pm 1.14 ; p=0.027$ ) was significantly decreased, whereas it was increased again on the 2 nd day following the exercise compared to the post-exercise value $(16.21 \pm 1.14$ vs. $18.33 \pm 1.23 ; p=0.011)$.

Conclusion: Tail length reduction is directly proportional to the decrement of DNA damage. Lowered tail length immediately after the exercise suggests that the applied isokinetic exercise may positively influence genotoxicity. This favorable effect returns within 2 days.

Key Words: Isokinetic exercise test, DNA damage, eccentric exercise.

Kılıç Toprak E, Ünver F, Kılıç Erkek Ö, et al. Investigation of the effects of an acute bout of isokinetic exercise on DNA damage in active male subjects. Pam Med J 2019;12:33-40.

\section{Giriş}

Egzersizin pek çok fizyolojik ve biyokimyasal süreç üzerindeki etkileri gösterilmiştir [1]. Orta şiddette düzenli yapılan egzersizler, sağlık için koruyucu olarak önerilirken [2]; eksantrik egzersiz gibi zorlu egzersizler biyomolekül, hücre ve dokularda çok çeşitli mekanizmalarla (kapiller endotelde, egzersiz esnasında hipoksireoksijenizasyon süreciyle), reaktif oksijen türleri (ROS) ve reaktif nitrojen türleri (RNS) artışına yol açarak hasara neden olabilmektedir [3]. Artan oksidatif stres; lipitlerde, proteinlerde ve DNA'da yıkıcı etkilere neden olabilmektedir [49]. Literatürde, fiziksel aktivitenin DNA üzerine etkilerini inceleyen az sayıda ve birbirinden farklı, çelişkili sonuçlara sahip çalışmalar vardır. Bunlardan bazıları egzersizin DNA'da hasara yol açtığını, bazıları hiçbir etkisinin olmadığını ve bazıları ise DNA hasarını azalttığını göstermektedir [1, 10-12]. Bu farklılıkların sebebi olarak uygulanan egzersizin tipi, süresi, şiddeti ve egzersize katılan bireylerin aktivite durumlarındaki değişiklikler ile DNA hasarı ölçüm yöntemlerindeki farklılıklar gösterilmiştir [1, 10-12]. Fiziksel olarak aktif olmanın genel olarak oksidatif hasara karşı vücudu koruyucu olduğu ayrıca DNA stabilitesini de etkileyebildiği ileri sürülmektedir [13, 14].

İokinetik egzersizler; konsantrik ve eksantrik olarak farklı açısal hızlarda uygulanabilen ve kaslara hareket genişliğinin her bir noktasında dirençuygulayan, diğer egzersizlere göre pekçok avantajı olduğu iyi bilinen, çok etkin güçlendirme egzersizleridir [15, 16]. Gerek sakatlıkları önlemek ve gerekse performansı arttırmak için kuvvet ve güç oranlarının tespiti önemlidir [16]. Alt ekstremite kas kuvvetinin saptanması ve sporcuların antrenman programlarının bu doğrultuda hazırlanması performans artışı açısından büyük önem taşımaktadır [17, 18]. İzokinetik dinamometreler, hareketin hem konsantrik hem de eksantrik fazda kas kuvvetini değerlendirebilmektedir [19, 20]. Eksantrik kas aktivitesi, konsantrik kasılmaya göre pek çok açıdan üstündür. Eksantrik kas kasılmasıyla yaklaşık \% 40-60 daha fazla kas kuvvet kazanımı elde edilebilmekte ve ayrıca kan akımının değişimiyle inflamasyon için faydalı etki oluşabilmektedir [21, 22]. Tüm bu nedenlerle, eksantrik egzersizler spor bilimciler, egzersiz fizyologları ve klinik rehabilitasyon amaçlı pek çok alanda yaygın olarak kullanılmaya başlanmıştır [20]. Ancak günümüze kadar yapılan literatür taraması sonucunda fiziksel olarak aktif bireylerde, izokinetik test cihazıyla uygulanan tek seanslık eksantrik tipte egzersizin Comet analizi kullanılarak DNA hasarı üzerine etkisi henüz araştırılmamıştır. Comet testi ile DNA hasarının kantitatif olarak saptanmasında; kuyruk uzunluğu, kuyruk yoğunluğu ve kuyruk momenti parametreleri sıkça kullanılmaktadır. Kuyruk uzaması hasar ile doğru orantılıdır. Ayrıca kuyruktaki floresan yoğunluğu ve kuyruk momenti de DNA hasarı derecesi ile paraleldir [23].

Yukarıdaki bilgiler ışığında, aktif bireylerde tek seanslık egzantrik egzersizin Comet yöntemiyle değerlendirilen DNA hasarını etkileyeceği şeklindeki hipotezimizi test etmek amacıyla, sağlıklı, aktif, erkeklerde izokinetik test cihazıyla uygulanan tek seanslık eksantrik tipte egzersizin DNA hasarı üzerine olası etkilerinin Comet analiziyle incelenmesi amaçlanmıştır.

\section{Gereç ve yöntem}

Çalışmaya 11 sağlıklı aktif erkek öğrenci dahil edilmiştir (ort yaş 19,45 $\pm 0,31$, boy 176,09 $\pm 1,99$ $\mathrm{cm}$, kilo $68,53 \pm 2,54 \mathrm{~kg}$ ). Öğrenciler düzenli spor aktivitesine katılmayan ancak haftada 3 
gün yüzme ve fitness gibi uygulamalı ders alan bireylerdir. Çalışmaya dahil edilme ve çıkarılma kriterleri aşağıda ayrıntıı şekilde açıklanmıştır.

\section{Öğrencilerin çalışmaya dahil edilme kriterleri:}

18-30 yaş arası, çalışmadan en az 6 ay öncesinde herhangi bir alt vücut direnç antrenmanına katımamış olan, bildiği ek sistemik hastalığı olmayan, ilaç kullanmayan, sağlıklı erkek bireyler alınmıştır. Denekler özellikle erkek seçilmiş olup çalışmanın homojenitesi sağlanmaya çalışılmıştır. Ayrıca çalışmamızda inceleyeceğimiz parametreler kadın cinsiyet hormonlarından etkilenmektedir; bunun etkisinin ekarte edilmesi amacıyla sadece erkekler dahil edilmiştir.

\section{Öğrencilerin dışlanma kriterleri:}

Diz ve kalça yaralanmasına sahip olmak; Reçeteli ilaç ve suplement kullanmak (örn: protein ve kreatin suplementleri, nonsteroid antiinflamatuvar ilaçlar); Herhangi bir ortopedik, kardiovasküler ve metabolik patolojiye sahip olmak; Vejeteryan beslenme tipine sahip olmak şeklinde belirlenmiştir.

Çalışma öncesinde bireylerin her birine araştırma ile ilgili karşılaşılabilecek risk ve rahatsızlıkları içeren yazılı ve sözlü ayrıntılı bilgi verilmiştir. Üniversitemizin Girişimsel Olmayan Klinik Araştırmalar Etik Kurulu'ndan onay (onay no: 60116787-020/27445; 18/04/2017) alınmıştır. Bireylerin egzersiz ölçümleri Spor Bilimleri Fakültesi Performans Laboratuvarı'nda yapılmış ve egzersizlerden hemen önce, hemen sonra ve 2 gün sonra alınan kan örneklerinde DNA hasar parametreleri Tıp Fakültesi Fizyoloji AD laboratuvarlarında çalışılmıştır.

Yapılan ölçümler aşağıda listelenmiştir.

\section{Egzersiz protokolü}

Bireylerin standart izokinetik ezgersiz ölçümleri alt ekstremite eksantrik kas kuvvet ölçüm testi esas alınarak yapılmıştır. Tüm bireyler aynı hafta içinde teste alınmıştır. Tüm kas kuvveti ölçümleri bireyler oturur pozisyonda, kalça eklemi $85^{\circ}$ fleksiyondayken yapılmıştır. Ayrıca uyluk üzerinden bantlarla diz eklemi sabitlenmiştir.

\section{1. İokinetik kuvvet egzersiz testi}

Egzersiz testi öncesi ısınma protokolü olarak, bireylerden 10 tekrarlı çömelme, adım alma, sıçrama yapmaları ve ayrıca bisiklette 70 w 5 dk egzersiz yapmaları istenmiştir. Bireylerin diz fleksiyon/ekstansiyon kuvvetleri izokinetik dinamometre (Humac Norm Testing Rehabilitation system, CSMI Medical Solutions, USA) kullanılarak ölçülmüştür. İzokinetik sistemde uygulanan test protokolleri egzersiz olarak da kullanıldığı için eksantrik kuvvet ölçümünde kullanılan test protokolü egzersiz seansı olarak uygulanmıştır [24]. Dominant dizlerin quadriceps ve hamstring kas kuvvetleri $30 \%$ ve $120 \%$ açısal hızlarda eksantrik modda test edilmiştir. Her iki hız için 2 tekrarlı alıştırma uygulanmış ve ölçümler; $30 \%$ sn'de 3 maksimal tekrar, $120 \%$ sn'de 4 maksimal tekrar olarak yaptırılmıştır. Egzersizlerden sonra soğuma için 1'er dakika 3 set olarak quadriceps ve hamstring kaslarına germe uygulanmıştır. Tepe tork fonksiyonel oranı için fleksör ve ekstansörlerin eksantrik kuvvetleri hesaplanmıştır. Test esnasında daha yüksek performans sergileyebilmeleri açısından denekler sözel olarak cesaretlendirici ifadelerle desteklenmiştir. Öğrencilere ısınma ve test protokolü sonrası herhangi bir skala kullanılarak ağrı ve yorgunluk derecesi sorgulaması yapılmamış; ancak ısınma periyodu sonrası öğrenciler bir şikayet belirtmezken, test sonrası ciddi yorgunluk ve ağrı ifade etmişlerdir.

\section{Venöz kan örneklerinin toplanması}

Tüm bireylerden, izokinetik egzersiz testi öncesi, hemen sonrası ve egzersizi izleyen 2. gün yaklaşık 15 'er $\mathrm{ml}$ venöz kan alınmıştır. DNA hasarı ölçümleri için, Comet analizi, kan EDTA'ı tüplere alınmak sureti ile gerçekleştirilmiştir. Aynı gün taze kandan lenfosit izolasyonu yapılmış, örnekler Comet analizinin yapılacağı güne kadar $-80^{\circ} \mathrm{C}$ 'de saklanmıştır.

\subsection{DNA hasarı ölçümü (Alkali Comet Ana- lizi):}

Bireylerden pıhtılaşması engellenmiş kan 5 ml'lik bir tüpe alınarak 1:1 oranında izotonik fosfat tamponu (PBS) ile seyreltilmiştir. Bu 10 ml'lik seyreltilmiş kan içinde $3 \mathrm{ml}$ Ficol-1077 olan bir başka tüpe aktarılarak 400 g'de 20 dakika santrifüj işlemine tabi tutulmuştur. Santrifüjden sonra elde edilen pellet $1 \mathrm{ml}$ RPMI ile 2-3 kez yıkandıktan sonra, hemositometre ile sayılmış 
ve 100 mikrolitrede $2 \times 10^{4}$ hücre olacak şekilde ayarlanmıştır. Bu şekilde hazırlanmış lenfosit süspansiyonundan 80 mikrolitre alınarak $100 \mu \mathrm{L}$ $\% 0,5^{\prime}$ lik $\mathrm{Ca}^{2+}$ ve $\mathrm{Mg}^{+}$içermeyen PBS ile $37^{\circ} \mathrm{C}$ ' de hazırlanan "Low melting agaroz" (LMA) ile resüspanse edilmiş, LMA + hücre karışımı önceden \%1'lik "normal melting agaroz" (NMA) ile kaplanmış olan lam üzerine ince bir tabaka halinde dökülmüştür. 30 dakika buz üzerinde bekletildikten sonra 3. tabaka olarak $70 \mu \mathrm{L} \% 0,5$ 'lik LMA ile kaplanmış ve tekrar 10 dakika buz üzerinde bekletilmiştir. Daha sonra lam hücresel proteinleri uzaklaştırmak amacıyla, pH'ı 10 olan soğuk lizis bağlama tamponu ile 60 dakika boyunca $+4^{\circ} \mathrm{C}$ de muamele edilmiştir. Lizis işlemi sonrası lamlar yatay jel elektroforezine aktarılmış ve yeni hazırlanmış alkalin elektroforez tamponunda 30 dakika süre ile inkübe edilmiştir. Bu sürenin sonunda lamlar yatay elektroforez tankına konularak $+4^{\circ} \mathrm{C}$ ' de, $300 \mathrm{~mA}$ akım altında 30 dakika boyunca elektroforez işlemine tabi tutulmuştur. Elektroforez işlemini takiben, lamlar nötralizasyon tamponu $(0,4 \mathrm{M}$ Tris- $\mathrm{HCl}$, $\mathrm{pH}=7,5)$ ile alkali ve deterjanları uzaklaştırmak amacıyla 3 kez 5 dakika $+4^{\circ} \mathrm{C}$ 'de yıkanmıştır. Nötralizasyon işlemi sonrası lamlar $60 \mu \mathrm{L}$ etidyum bromid $(2 \mu \mathrm{L} / \mathrm{mL})$ ile boyanarak floresan mikroskobunda incelenmiş, olası DNA hasarı "Comet assay IV system (AutoComet)" program yazılımıyla değerlendirilmiştir.

Hasar değerlendirmesinde yazılım aracılığı ile kuyruk uzunluğu ( $T L$; “tail length", $\mu \mathrm{m}$ ), kuyruk yoğunluğu (TI; "tail intensity", kuyruk kısmındaki DNA yüzdesi, (\%) T-DNA), Kuyruk
Momenti (TM; "tail moment", $\mu \mathrm{m}, \%$ T-DNA ile TL'nin çarpımının 100'e bölünmesi ile edilir) parametreleri 100 hücrede ölçülerek ortalamaları kullanılmıştır [23].

\section{Görüntü analizi}

Hasarsız hücrelerin DNA'ları incelendiğinde yuvarlak, kenarları daha az yoğun ve ortası parlak bir görünüm ile karşılaşılmaktadır. DNA'nın bu görünümü non-migrasyon olarak değerlendirilir. Eğer DNA hasarı oluşmaya başlamış ise DNA zincir kırılmalarına ve alkalilabil bölgelerin seviyesine bağlı olarak normalde düzgün kenarlı olan DNA görüntüsü, kırıklarının çekirdek dışına göçünün nedeniyle düzensiz kenarlı bir görüntü halini alır. Bu görünüme düşük-migrason denir. Hasar arttıkça hücreler kuyruklu yıldız (Comet, yüksek-migrasyon ) şeklini alır. Ayrıca kuyruktaki floresan yoğunluğu da DNA kırıklarının oluşup gövdeden kuyruğa göçtüğü anlamını taşmaktadır. Bu uzama hasar ile doğru orantılıdır [23].

Comet analizi kapsamında DNA hasarı, granülositler içinde yarı ömrü en uzun hücre olan lenfositlerin izolasyonu ile incelenmektedir (Şekil 1).

\section{İstatistiksel analiz}

Yapılan güç analizi sonucunda çalışmaya en az 11 kişi alındığında $\% 80$ güç elde edilebileceği hesaplanmıştır. Veriler SPSS 21.0 paket programılla analiz edilmiştir. Sürekli

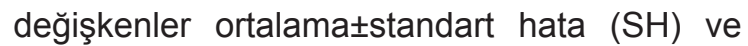
kategorik değişkenler sayı ve yüzde olarak verilmiştir. Dağılımların normalliği Shapiro Wilk

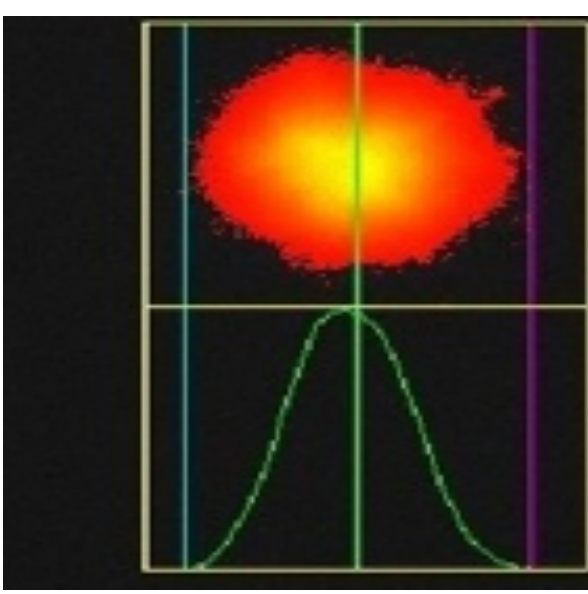

a

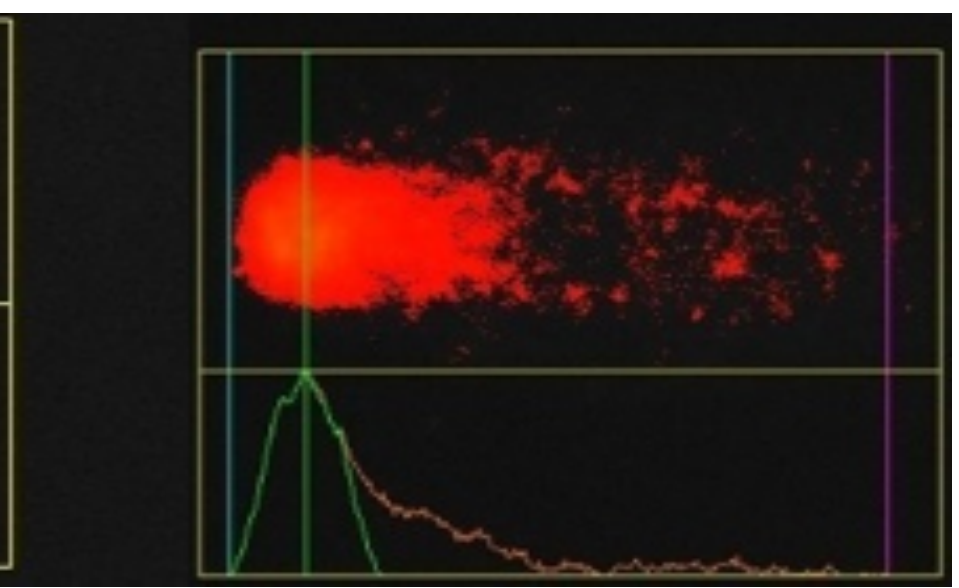

b

Şekil 1. Etidyum bromid ( $2 \mu \mathrm{L} / \mathrm{mL}$ ) ile boyanarak floresan mikroskobunda incelenmiş lenfosit görüntüleri a) Normal DNA b) Hasarlı DNA 
Testi ile incelenmiştir. Ortalamalar arasındaki farklılıklar Friedman Testi (post hoc Bonferroni düzeltmeli Wilcoxon eşleştirilmiş iki örnek testi) ile incelenmiştir. $p \leq 0,05$ değerler istatistiksel olarak önemli kabul edilmiştir.

\section{Bulgular}

Çalışmamıza katılan 11 sağlıklı aktif erkek öğrencinin Tablo 1'de uygulanan izokinetik egzersiz test protokolünün sonuçları sunulmuştur. Bireylerin DNA hasar parametreleri incelendiğinde, Comet analizi ile belirlenmiş genotoksisiteye ait sonuçlar Şekil 1 ve Tablo 2'de verilmiştir. Kuyruk uzunluğu egzersizden hemen sonra alınan kan örneklerinde anlamlı derecede azalırken (18,76 $\pm 3,08$ 'e karşın $16,21 \pm 1,14 ; p=0,027)$; iki gün sonra elde edilen toparlanma örneklerinde egzersiz sonrasına

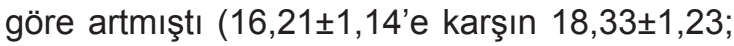
$p=0,011$ ) (Tablo 2). Diğer ölçümlerde istatistiksel olarak anlamlı bir değişim belirlenmemiştir.

\section{Tartışma}

Sağlıklı aktif erkek bireylerde, izokinetik test cihazıyla uygulanan tek seanslık eksantrik tipte egzersizin DNA hasarı üzerine olası etkilerini incelemek amacıyla planladığımız çalışma, literatürdeki konu ile ilgili ilk araştırmadır. Bulgularımız, aktif erkek bireylerde uygulanan izokinetik egzersiz testiyle, kuyruk uzunluğunun egzersizden hemen sonra azaldığını ve egzersizden 2 gün sonra yeniden arttığını göstermektedir. Bu durum, uyguladığımız egzersiz testinin aktif bireylerde genotoksisite üzerine koruyucu etki oluşturabildiğini ve DNA hasarına karşı tamir mekanizmalarının devreye girdiğini destekler niteliktedir. Bu olumlu etkinin 2 gün sonra alınan kan örneklerinde tekrar egzersiz öncesi değerlere yaklaştığı tespit edilmiştir.

Tek hücre jel elektroforezi veya sıklıkla tercih edilen diğer adıyla "Comet (kuyruklu yıldız) Assay" yöntemi son yıllarda genişleyen

Tablo 1. Bireylerin Dominant Ekstremite $30 \%$ sn ve $120 \%$ sn Hamstring ve Kuadriseps kaslarının izokinetik kas kuvvet değerleri

\begin{tabular}{lc}
\hline Eksantrik Kas Kuvveti & \\
\hline $\begin{array}{l}\text { Ekstansiyon } \\
\text { (Kuadriseps kası) }\end{array}$ & Ortalama \pm Standart hata \\
$30 \%$ sn Pik Tork (Nm) & $236,82 \pm 20,21$ \\
$30 \%$ n (\%Vücut ağırlığı) (Nm/kg) & $334,91 \pm 22,50$ \\
$120 \%$ sn Pik Tork (Nm) & $217,73 \pm 12,34$ \\
$120 \%$ sn (\%Vücut ağırığı) (Nm/kg) & $308,91 \pm 11,26$ \\
Fleksiyon & \\
(Hamstring kası) & $128 \pm 15,71$ \\
$30 \%$ sn Pik Tork (Nm) & $178,82 \pm 17,98$ \\
$30 \%$ sn (\%Vücut ağırlığı) (Nm/kg) & $114,18 \pm 10,60$ \\
$120 \%$ sn Pik Tork (Nm) & $296,55 \pm 136,82$ \\
$120 \%$ sn (\%Vücut ağırığı) (Nm/kg) & \\
\hline
\end{tabular}

Nm: Newton-metre

Tablo 2. Bireylerin DNA hasar parametreleri

\begin{tabular}{cccc}
\hline DNA HASAR PARAMETRELERi & $\begin{array}{c}\text { Egzersiz öncesi } \\
(\mathbf{n}=\mathbf{1 1})\end{array}$ & $\begin{array}{c}\text { Egzersiz sonrası } \\
(\mathbf{n = 1 1 )}\end{array}$ & $\begin{array}{c}\text { 2.gün toparlanma } \\
(\mathbf{n}=\mathbf{5})\end{array}$ \\
\hline Kuyruk uzunluğu $(\boldsymbol{T L})(\boldsymbol{\mu m})$ & $18,76 \pm 3,08$ & $\mathbf{1 6 , 2 1 \pm 1 , 1 4 ^ { * }}$ & $\mathbf{1 8 , 3 3 \pm 1 , 2 3 ^ { * * }}$ \\
Kuyruk yoğunluğu $(\boldsymbol{T I})(\%)$ & $6,81 \pm 1,56$ & $5,90 \pm 1,62$ & $6,53 \pm 1,05$ \\
Kuyruk momenti $(\boldsymbol{T M})(\boldsymbol{\mu m})$ & $0,85 \pm 0,76$ & $0,56 \pm 0,18$ & $0,64 \pm 0,07$ \\
\hline
\end{tabular}

TL: tail length, TI: tail intensity; TM: tail moment; ${ }^{*} p<0,05$; egzersiz öncesinden fark; ${ }^{* *} p<0,05$ : egzersiz sonrasından fark 
uygulama alanı, güvenilirliği ve uygulamasının kolay olması bakımından kimyasal ve fiziksel etmenlerin canlılar üzerinde yol açtığı genotoksik ve sitotoksik etkilerin bir göstergesi olan DNA hasar seviyelerinin ölçülmesi için tercih edilen önemli bir yöntemdir [23]. Araştırıcı tarafından seçilen Cometler için çeşitli floresan parametreleri hesaplayacak çok sayıda yazılım bulunmaktadır. Bu yazılımlar ile DNA parçaları baş ve kuyrukt olarak iki ana bölüme ayrılabilmekte; çeşitli parametreler hesaplanabilmektedir. Floresan mikroskop ile incelenen preparatlarda zarar görmemiş DNA'lar comet (kuyruk) oluşturmazken, hasar görmüş DNA moleküllerindeki fragmentler farklı moleküler ağırlıklarına ve farklı elektrik yüklerine sahip olacaklarından elektriksel alanda farklı hızlarda hareket ederek çekirdekten dışarı doğru göç etmekte ve kuyruklu yıldız görünümü oluşturmaktadırlar (Şekil 1). Bu görünüm nedeniyle bu tekniğe "Comet" adı verilmiştir [23].

Yaşam biçimi değişikliklerinin insan DNA'sının hasar görmesine neden olabileceği bilinmektedir [25]. Literatürde bazı çalışmalar egzersize yanıt olarak DNA hasarı oluştuğunu belirtirken [19], bazıları da hiçbir değişim göstermemişlerdir $[26,27]$. Bu çalışmalarda egzersiz protokolleri ve egzersize katılan bireylerin fiziksel aktivite düzeyleri önemli rol oynamaktadır. Egzersizle oluşabilen düşük seviyedeki DNA hasarının, DNA hasarı tamir enzimlerinin upregülasyonu ve immün cevabın uyarılmasını sağlayarak faydalı etki sağlayabileceği bildirilmiştir [28]. Bu etki "hormesis" olarak bilinmektedir. Düşük seviyelerdeki hasar, organizmada koruyucu mekanizmaları upregüle edebilmektedir [28]. Bunlara ekolarak artmış fiziksel aktivite düzeyinin DNA hasarıyla ilişkili olmadığını, orta şiddetli fiziksel aktivitenin DNA hasarı oluşturmayıp aksine DNA onarım mekanizmalarını uyardığı gösterilmiştir [29].

Farklı tip egzersizlerin etkileri incelendiğinde; endurans sporcularında submaksimal koşu bandı egzersiziyle DNA hasarı oluşmadığı gösterilmiştir [12, 30]. Yine başka bir çalışmada genç ve yaşlı fiziksel olarak aktif erkek bireylerde, yokuş aşağı koşu egzersiziyle oksidatif DNA hasarı belirteci olan 8-hidroksi2'-deoksiguanozin (8-OHdG) seviyelerinde değişiklik oluşmadığı gösterilmiştir [31]. Akut veya kronik olarak orta şiddette yapılan egzersizin, DNA hasarı oluşturmadığı ancak uzun süreli ve yüksek şiddette egzersizlerde artmış DNA hasarı oluşabildiği öne sürülmüştür [32]. Soares ve ark. [33] 31 erkek bireye günde 60-75 dakika, haftada 3 gün, 16 hafta olacak şekilde kombine (aerobik-germe ve kuvvetlendirme) egzersiz programı uygulamışlar ve bu programın antioksidan kapasiteyi arttırarak lenfositlerde oluşabilecek DNA hasarına karşı koruyucu etkiler oluşturduğunu göstermişlerdir. Öte yandan, gen tedavisi olarak egzersizin incelendiği bir derlemede, insanlarda egzersizle DNA hasarı tamir mekanizmaları arasındaki ilişkinin halen net olmadığı belirtilmektedir [34].

Bizim çalışmamızda da yukarıdaki verilere benzer şekilde, uygulanan akut egzersiz protokolünün aktif bireylerde TI ve TM ile tespit edilen DNA hasarına sebep olmadığı, daha da fazlası, TL ile belirlenen DNA hasarına karşı koruyucu etki gösterdiği sonucuna ulaşılmıştır. Öte yandan, literatürde yorulana kadar yaptırılan eğimli koşu bandı egzersiziyle bireylerin lökositlerinde DNA hasarı oluşabildiği [10] ancak DNA hasarının derecesinin de egzersiz eğitimiyle azaldığı bildirilmiştir [35]. Bizim çalışmamızda da denekler aktif bireylerden oluşmaktadır. Uyguladığımız zorlayıcı egzersiz modelinin, yukarıdaki verilerle uyumlu şekilde DNA hasarı tamir mekanizmalarını upregüle etmiş olabileceği ileri sürülebilir.

Egzersize bağlı DNA hasarının zamana bağlı değişimlerini inceleyen çalışmalar da birbirleriyle çelişkili sonuçlara sahiptir [11, 33]. Niess ve ark'ı [11] yapmış oldukları çalışmada; antrene ve sedanter erkek bireylerde yorucu egzersiz sonrası [koşu bandında kademeli olarak artış yapılarak, yorulana kadar (antrenelerde max laktat: $12,9 \mathrm{mmol} / \mathrm{L}$, sedanterlerde max laktat: $12,2 \mathrm{mmol} / \mathrm{L}$ seviyesine çıkana kadar)] tek jel elektroforez ile periferal lökositlerde DNA hasarını değerlendirmişler ve hasar göstergesi olarak DNA migrasyonunu, egzersizden 24 saat sonra, her iki grupta da egzersiz öncesine göre anlamlı şekilde artmış; ancak bu artış antrene grupta daha az olduğunu bulmuşlardı. Hartmann ve ark. [10] 45 dk'lık koşu egzersizinden sonra DNA hasarı parametrelerinden TM'nin zamana bağlı değişimini değerlendirmişler ve bifazik etki oluştuğunu göstermişlerdir. Şöyle ki; egzersizden hemen sonra TM'de değişiklik saptanmazken, 1.gün artış, 2. gün azalma, 3 . gün artış, 4. gün yine azalma belirlemişlerdir 
[10]. Çalışmamızda, Hartmann ve ark'na benzer şekilde uyguladığımız akut şiddetli egzersiz protokolünün DNA üzerine etkilerinde zamana bağlı değişim gözlenmiştir. Bununla beraber, DNA hasarı belirteci olarak kullanılan parametrelerden TM yerine TL'de değişiklik gözlenmiştir. TL egzersizden hemen sonra artarken, 2 gün sonra, yani toparlanma sürecinde egzersiz öncesi seviyesine dönmüştür.

Sonuç olarak bulgularımız, aktif bireylerde uygulanan akut, şiddetli egzersiz protokolünün egzersizden hemen sonra bireyi DNA hasarına karşı koruyucu etki gösterebileceğini ancak bu etkinin 2 gün içinde ortadan kalktığını göstermektedir. Bu veriler ışığında, henüz net olarak ortaya konmamış olmasına rağmen egzersiz, DNA hasarı tamir mekanizmalarını uyarıcı bir strateji olarak incelenebilir. Çalışmamızda venöz kan örnekleri egzersiz öncesi, sonrası ve egzersizden 2 gün sonra toparlanma sürecinde toplanmıştır. Ancak egzersizden önce ve sonra 11 kişiden örnekler alınmasına rağmen 2 gün sonra toparlanma sürecinde kan vermeye sadece 5 kişi gelmiştir. Bu da toparlanma sürecindeki verilerimiz açısından çalışmamız için bir kısıtıııktır. Çalışma verilerinin sağlıklı aktif bireyler ve sporculara izokinetik egzersiz protokolleri önerileceğinde göz önüne alınması uygun olacaktır. Çalışmamızda DNA hasar göstergesi olan TL'nin egzersizden hemen sonra azalmış olması, bireylerin düzenli fiziksel aktivitelere katılıyor olması ve böylece zaman içinde egzersiz eğitimiyle, DNA hasarına karşı tamir mekanizmalarının devreye girmiş olmasından kaynaklanıyor olabilir. Uygulanan egzersiz protokolüne yanıt olarak oksidatif stres parametreleri, kas hasar belirteçleri (kreatin kinaz vb) ve tamir mekanizmalarının değerlendirilmemiş olması araştırmanın kısıtlııkları olarak sayılabilir. Çalışma konu ile ilgili bir ön çalışma niteliğinde değerlendirilebilir. Gelecekte farklı egzersiz protokollerinin DNA üzerindeki etkilerinin net olarak ortaya konması, bu etkilerde rol oynayan mekanizmaların açıklanabilmesi için farklı antrenman düzeyindeki denekleri içeren daha kapsamlı ve zamana bağlı değişimleri inceleyen çalışmalara intiyaç vardır. Hem DNA hasarı hem de tamir mekanizmalarının gen seviyesinde araştırıması konunun netleştirilmesine katkı sağlayacaktır.

Çıkar İlişkisi: Yazarlar çıkar ilişkisi olmadığı beyan eder.

\section{Kaynaklar}

1. Briviba K, Watzl B, Nickel K, et al. A half-marathon and a marathon run induce oxidative DNA damage, reduce antioxidant capacity to protect DNA against damage and modify immune function in hobby runners. Redox Rep 2005;10:325-331.

2. Radak Z, Chung HY, Goto S. Systemic adaptation to oxidative challenge induced by regular exercise. Free Radic Biol Med 2008;44:153-159.

3. Leeuwenburgh $C$, Heinecke JW. Oxidative stress and antioxidants in exercise. Curr Med Chem 2001;8:829838.

4. Wagner $\mathrm{KH}$, Reichhold S, Hölzl C, et al. Well-trained, healthy triathletes experience no adverse health risks regarding oxidative stress and DNA damage by participating in an ultra-endurance event. Toxicology 2010;278:211-216.

5. Cogswell ME, Weisberg P, Spong C. Cigarette smoking, alcohol use and adverse pregnancy outcomes: implications for micronutrient supplementation. J Nutr 2003;133:1722-1731.

6. Ji BT, Shu $X O$, Linet $M S$, et al. Paternal cigarette smoking and the risk of childhood cancer among offspring of nonsmoking mothers. J Natl Cancer Inst 1997;89:238-244.

7. Kim YJ, Hong YC, Lee $\mathrm{KH}$, et al. Oxidative stress in pregnant women and birth weight reduction. Reprod Toxicol 2005;19:487-492.

8. Raimondi S, Garte S, Sram RJ, et al. Effects of diet on biomarkers of exposure and effects, and on oxidative damage. Mutat Res 2007;620:93-102.

9. Jenkins FJ, Van Houten B, Bovbjerg DH. Effects on DNA Damage and/or Repair Processes as Biological Mechanisms Linking Psychological Stress to Cancer Risk. J Appl Biobehav Res 2014;19:3-23.

10. Hartmann A, Plappert U, Raddata K, Grünert-Fuchs M, Speit G. Does physical activity induce DNA damage? Mutagenesis 1994;9:269-272.

11. Niess A, Hartmann A, Grunert-Fuchs M, Poch B, Speit G. DNA damage after exhaustive treadmill running in trained and untrained men. Int $\mathrm{J}$ Sports Med 1996;17:397-403.

12. Peters E, Eden M, Tyler N, Ramautar A, Chuturgoon AA. Prolonged exercise does not cause lymphocyte DNA damage or increased apoptosis in well-trained endurance athletes. Eur J Appl Physiol 2006;98:124131.

13. Reichhold $S$, Neubauer $O$, Ehrlich $V$, Knasmüller $S$, Wagner KH. No acute and persistent DNA damage after an Ironman triathlon. Cancer Epidemiol Biomarkers Prevent 2008;17:1913-1919.

14. Reichhold S, Neubauer $O$, Hoelzl $C$, et al. DNA damage in response to an Ironman triathlon. Free Radic Res 2009;43:753-760. 
15. Coudeyre E, Jegu AG, Giustanini M, Marrel JP, Edouard $P$, Pereira $B$. Isokinetic muscle strengthening for knee osteoarthritis: A systematic review of randomized controlled trials with meta-analysis. Ann Phys Rehabil Med 2016;59:207-215.

16. Pincivero DM, Lephart SM, Karunakara RA. Reliability and precision of isokinetic strength and muscular endurance for the quadriceps and hamstrings. Int J Sports Med 1997;18:113-117.

17. Newton RU, Gerber A, Nimphius S, et al. Determination of functional strength imbalance of the lower extremities. J Strength Cond Res 2006;20:971-977.

18. Impellizzeri $F M$, Rampinini $E$, Maffiuletti $N$, et al. A vertical jump force test for assessing bilateral strength asymmetry in athletes. Med Sci Sports Exerc 2007;39:2044-2050.

19. Douglas J, Pearson S, Ross A, McGuigan M. Chronic adaptations to eccentric training: A systematic review. Sports Med 2017;47:917-941

20. Mike JN, Cole N, Herrera C, Van Dusseldorp T, Kravitz $L$, Kerksick CM. The effects of eccentric contraction duration on muscle strength, power production, vertical jump and soreness. J Strength Cond Res 2017;31:773786.

21. Hollander DB, Kraemer RR, Kilpatrick MW, et al. Maximal eccentric and concentric strength discrepancies between young men and women for dynamic resistance exercise. J Strength Cond Res 2007;21:34-40.

22. Roig M, O'Brien K, Kirk G, et al. The effects of eccentric versus concentric resistance training on muscle strength and mass in healthy adults: A systematic review with meta-analysis. Br J Sports Med 2009;43:556-568.

23. Nandhakumar $S$, Parasuraman $S$, Shanmugam MM, Rao KR, Chand P, Bhat BV. Evaluation of DNA damage using single-cell gel electrophoresis (Comet Assay). J Pharmacol Pharmacother 2011;2:107-111.

24. Arden CL, Pizzari T, Wollin MR, Webster KE. Hamstrings strength imbalance in professional football (soccer) players in Australia. J Strength Cond Res 2015;29:9971002.

25. Løhr M, Jensen A, Eriksen L, Grønbæk M, Loft S, Møller P. Age and metabolic risk factors associated with oxidatively damaged DNA in human peripheral blood mononuclear cells. Oncotarget 2015;6:2641-2653.

26. Pilger A, Germadnik D, Formanek D, Zwick $H$, Winkler N, Rüdiger HW. Habitual long-distance running does not enhance urinary excretion of 8hydroxydeoxyguanosine. Eur J Appl Physiol Occup Physiol 1997;75:467-469.

27. Sumida S, Doi T, Sakurai M, Yoshioka Y, Okamura K. Effect of a single bout of exercise and beta-carotene supplementation on the urinary excretion of 8-hydroxydeoxyguanosine in humans. Free Radic Res 1997:27;607-618.
28. Kaiser J. Sipping from a poisoned chalice. Science 2003;302:376-379.

29. Cash SW, Beresford SA, Vaughan TL, et al. Recent physical activity in relation to DNA damage and repair using the comet assay. J Phys Act Health 2014;11:770776.

30. Umegaki K, Daohua P, Sugisawa A, Kimura M, Higuchi $M$. Influence of one bout of vigorous exercise on ascorbic acid in plasma and oxidative damage to DNA in blood cells and muscle in untrained rats. J Nutr Biochem 2000;11:401-407.

31. Sacheck JM, Milbury PE, Cannon JG, Roubenoff R, Blumberg JB. Effect of vitamin $E$ and eccentric exercise on selected biomarkers of oxidative stress in young and elderly men. Free Radic Biol Med 2003;34:1575-1588.

32. Sato $Y$, Nanri $H$, Ohta $M$, Kasai $H$, Ikeda $M$. Increase of human MTH1 and decrease of 8-hydroxydeoxyguanosine in leukocyte DNA by acute and chronic exercise in healthy male subjects. Biochem Biophys Res Commun 2003;305:333-338.

33. Soares JP, Silva AM, Oliveira MM, Peixoto F, Gaivão I, Mota MP. Effects of combined physical exercise training on DNA damage and repair capacity: role of oxidative stress changes. Age (Dordr) 2015;37:9799.

34. Schmidt RH, Nickerson JM, Boatright JH. Exercise as Gene Therapy: BDNF and DNA Damage Repair. Asia Pac J Ophthalmol (Phila) 2016;5:309-311.

35. Hartmann A, Niess AM, Grünert-Fuchs M, Poch B, Speit G. Vitamin E prevents exercise-induced DNA damage. Mutat Res 1995;346:195-202.

Teşekkür: Çalışmamıza katılan deneklerimize teşekkür ederiz. Çalışmamız 43. Ulusal Fizyoloji Kongresinde poster olarak sunulmuştur, 7-10 Eylül/Pamukkale Üniversitesi, Denizli. 